\title{
Polymorphisms and haplotypes of the gene encoding the estrogen-metabolizing CYP19 gene in Korean women: no association with advanced-stage endometriosis
}

\author{
Sung Eun Hur $\cdot$ Sara Lee $\cdot$ Ji Young Lee \\ Hye-Sung Moon · Hyung Lae Kim · Hye Won Chung
}

Received: 12 March 2007/ Accepted: 16 June 2007/Published online: 9 August 2007

(C) The Japan Society of Human Genetics and Springer 2007

\begin{abstract}
A variety of factors affect the development of endometriosis, including hormonal status and genetic factors. The growth of endometriosis is stimulated by local estrogen production in conjunction with circulating estrogen. The CYP19 gene encodes a steroid aromatase that catalyses the conversion of C-19 androgens to estrogens. This study investigated whether polymorphisms of the CYP19 gene are associated with the risk of advanced endometriosis in Korean women. Blood samples were collected from 224 female patients with endometriosis of stages III and IV, as diagnosed by both pathologic and laparoscopic findings, and from a control group comprising of 188 women undergoing laparoscopic surgery or laparotomy for nonmalignant lesions. Single-nucleotide polymorphisms, restriction fragment length polymorphisms, and tetranucleotide tandem repeat polymorphisms were discriminated by the polymerase chain reaction (PCR). Haplotype analysis was also performed. CYP19 115T >C,
\end{abstract}

\section{S. E. Hur}

Department of Obstetrics and Gynecology,

Konyang University College of Medicine, Daejeon,

South Korea

S. Lee $\cdot$ H.-S. Moon $\cdot$ H. W. Chung $(\square)$

Department of Obstetrics and Gynecology,

Ewha Womans University Mokdong Hospital,

911-1 Yang-Cheon-Ku Mock-6-Dong,

158-710 Seoul, South Korea

e-mail: hyewon@ewha.ac.kr

J. Y. Lee

Department of Obstetrics and Gynecology,

Konkuk University School of Medicine, Seoul, South Korea

H. L. Kim

Department of Biochemistry, Ewha Womans University

School of Medicine, Seoul, South Korea
$240 \mathrm{G}>\mathrm{A}$, and $1531 \mathrm{C}>\mathrm{T}$ polymorphisms and [TTTA] $n$ tetranucleotide repeat polymorphisms in the CYP19 gene and their haplotypes were not significantly associated with the risk of endometriosis. The risk of endometriosis also did not increase significantly with the number of higher risk alleles of the CYP19 gene. In conclusion, our findings suggest that CYP19 genetic polymorphisms are not associated with advanced-stage endometriosis in Korean women.

Keywords CYP19 gene polymorphism - Haplotype · Estrogen-metabolizing gene $\cdot$ Advanced-stage endometriosis

\section{Introduction}

Endometriosis is one of the most common gynecologic disorders, but its etiology and pathogenesis remain obscure. There is increasing evidence that endometriosis is inherited as a complex genetic trait, implying that multiple gene loci interact with both each other and the environment to produce the phenotype disease (Kennedy 1997). Recent genetic studies have found an association between the development of endometriosis and the polymorphisms of several genes (Cramer et al. 1996; Baranova et al. 1997; Watanabe et al. 2001; Chang et al. 2002; Wieser et al. 2002; Hur et al. 2005), including the genes related to estrogen metabolism (Georgiou et al. 1999; Kitawaki et al. 2001; Kado et al. 2002).

The growth of endometriosis increases with the level of estrogen. Endometrial implants contain estrogen, progesterone, and androgen receptors (Lessey et al. 1989; Prentice et al. 1992; Bergqvist and Fernö 1993), as well as aromatase, an enzyme that catalyses the conversion of 
androgens to estrogens. Ectopic endometriotic implants respond to ovarian hormonal changes. Local estrogen production in conjunction with circulating estrogen stimulates the growth of endometriosis, which is mediated by the estrogen receptor (Kitawaki et al. 1997).

Aromatase is a member of the cytochrome P450 enzyme family and is encoded by the CYP19 gene. CYP19 is one of the essential enzymes for the biosynthesis of estrogen, which converts androgens into estrogens, androstenedione into estrone, and testosterone into estradiol. Although endometriotic implants express aromatase, endometrial tissue from uterine-disease-free women does not exhibit aromatase activity (Kitawaki et al. 1999; Bulun et al. 2004). In contrast, aromatase enzyme activity and increased mRNA levels are readily detectable in endometriosis (Bulun et al. 2005). We speculated that the onset or growth of endometriosis might be associated with an aberrant transcription of CYP19.

The CYP19 gene has several polymorphisms: a [TTTA] $n$ tetranucleotide repeat polymorphism in intron 4 (Healey et al. 2000; Kristensen et al. 2000), a 115T>C polymorphism in exon 2 (Trp39Arg) (Miyoshi et al. 2000), a silent $240 \mathrm{~A}>\mathrm{G}$ polymorphism at codon 80 in exon 3 (Siegelmann-Danieli and Buetow 1999), a 790C $>$ T polymorphism in exon 8 (Arg264Cys) (Toda et al. 1990; Kristensen et al. 2000; Lee et al. 2003), and a 1531C $>\mathrm{T}$ polymorphism in the $3^{\prime}$ untranslated region of exon 10 (Sourdaine et al. 1994). CYP19 gene polymorphisms are reportedly associated with estrogen-dependent diseases, such as uterine myoma, endometriosis, breast cancer, and endometrial cancer (Hirose et al. 2004; Bulun et al. 2005; Paynter et al. 2005).

The development of endometriosis depends on estrogen, and several features of this disease can be explained by the overproduction of estrogen. Endometriosis is currently treated using hormones that aim to lower the circulation level of estrogen. Genetic polymorphisms in the estrogensynthesizing or estrogen-metabolizing enzymes may be responsible for interindividual variations in the levels and the activity of circulating estrogen, and may play an important role in interindividual variations in endometriosis by altering the local estrogen production or circulation levels of estrogen.

We evaluated whether the $115 \mathrm{~T}>\mathrm{C}, 240 \mathrm{G}>\mathrm{A}$, and $1531 \mathrm{C}>\mathrm{T}$ polymorphisms and their haplotypes and also [TTTA] $n$ tetranucleotide repeat polymorphisms in CYP19 are associated with the risk of endometriosis.

In this study, we have investigated the potential influence of CYP19 polymorphisms in Korean women with and without endometriosis to assess the risk of individual genotypes or haplotypes that alter metabolizing capabilities for estrogen in the development of endometriosis.

\section{Material and methods}

\section{Subjects}

The study protocol was approved by the Institutional Review Board on the Use of Human Subjects in Research at Ewha Womans University and informed consent was obtained from each patient. The endometriosis patients had undergone laparotomy or laparoscopy from the Obstetrics and Gynecology Department at Ewha Womans University Hospital. The patients consisted of 224 unrelated Korean women and were diagnosed as advanced-stage endometriosis (stages III and IV) by both pathological and laparoscopic findings according to the revised American Fertility Society classification of endometriosis (American Fertility Society 1985). The 188 women undergoing laparoscopic surgery or laparotomy for nonmalignant lesions, such as benign ovarian cyst, were included in the control group. Blood samples were collected for DNA extraction.

\section{T $>$ C genotyping}

Polymerase chain reaction (PCR) with confronting two-pair primers (Hirose et al. 2004) was used for the $115 \mathrm{~T}>\mathrm{C}$ polymorphism, with the amplification for CYP19 being achieved using primers forward 1: 5'-ATCTGTACTGTACAGCACC-3' and reverse 1: 5'-ATGTGCCCTCATAA TTCCG-3' (Bioneer, Seoul, Korea) for the C (Arg) allele and forward 2: 5'-GGCCTTTTTCTCTTGGTGT-3' and reverse 2: 5'-CTCCAAGTCCTCATTTGCT-3' (Bioneer, Seoul, Korea) for the T (Trp) allele. Genomic DNA (30$100 \mathrm{ng}$ ) was added to $25 \mu \mathrm{l}$ of reaction medium with $0.15 \mathrm{mM}$ deoxynucleotide triphosphates, $25 \mathrm{pmol}$ of each primer, 5 units of AmpliTaq Gold, and $2.5 \mu \mathrm{l}$ of GeneAmp $10 \times$ PCR buffer, including $15 \mathrm{mM} \mathrm{MgCl} 2$ (Perkin-Elmer, Foster City, CA, USA). All PCR amplifications were carried out using a GeneAmp 9600 thermal cycler (PerkinElmer). Amplification conditions were $10 \mathrm{~min}$ of initial denaturation at $95^{\circ} \mathrm{C}$, followed by 30 cycles of $1 \mathrm{~min}$ at $95^{\circ} \mathrm{C}, 1 \mathrm{~min}$ at $54^{\circ} \mathrm{C}$, and $1 \mathrm{~min}$ at $72^{\circ} \mathrm{C}$ and $5 \mathrm{~min}$ of final extension at $72^{\circ} \mathrm{C}$. The amplified DNA was visualized on $2 \%$ agarose gel with ethidium bromide staining. The genotypes were distinguished as follows: a 200-bp band for the $\mathrm{T}$ allele, a 264-bp band for the $\mathrm{C}$ allele, and a 427-bp common band.

\section{$240 \mathrm{~A}>\mathrm{G}$ genotyping}

For determination of the $240 \mathrm{~A}>\mathrm{G}$ polymorphism at position Val80 in CYP19, a 188-bp PCR product was generated. The PCR was carried out in a $25-\mu l$ reaction mixture containing $200 \mathrm{ng}$ genomic DNA, $2.0 \mathrm{mM}$ $\mathrm{MgCl}_{2}, 250 \mu \mathrm{M}$ deoxy-NTPs, $0.5 \mu \mathrm{M}$ of each primer, and 
0.5 U Taq DNA polymerase. The primer sequences were as follows: forward, 5'-AGTAACACAGAACAGTTGCA3'; reverse, 5'-TCCAGACTCGCATGAATTCTCCGTA-3' (Bioneer). A mismatch ( $\mathrm{G}$ instead of $\mathrm{A}$ ) was introduced in the reverse primer to create a restriction site for the Rsal enzyme. All PCR amplifications were carried out using a GeneAmp 9600 thermal cycler (Perkin-Elmer). After an initial denaturation at $95^{\circ} \mathrm{C}$ for $5 \mathrm{~min}, 35$ cycles of amplification with denaturation at $95^{\circ} \mathrm{C}$ for $30 \mathrm{~s}$, annealing at $56^{\circ} \mathrm{C}$ for $30 \mathrm{~s}$, and extension at $72^{\circ} \mathrm{C}$ for $30 \mathrm{~s}$ were performed, followed by a final extension step of $7 \mathrm{~min}$ at $7^{\circ} \mathrm{C}$. The PCR product was digested overnight with $5 \mathrm{U}$ Rsa1 followed by size separation and visualization of the restriction fragments by electrophoresis on $1 \%$ agarose gels stained with ethidium bromide and viewed by UV illumination. The presence of the $G$ variant in CYP19 resulted in digestion of the 188-bp amplicon to two smaller fragments of $164 \mathrm{bp}$ and $24 \mathrm{bp}$. Only one 188-bp fragment was seen in subjects with the AA genotype. In subjects with the GA genotype, two bands of 188 bp and 164 bp were seen, whereas in those subjects homozygous for the $\mathrm{G}$ variant (GG), only one 164-bp PCR fragment was present.

\section{CYP19 1531C>T genotyping}

CYP19 C1558-T genotyping for polymorphisms were carried out by PCR as described by Tofteng et al. (2004) with minor modifications. A 190-bp DNA fragment, including the polymorphic site in exon 10, was amplified by PCR. Because there are no naturally occurring restriction sites capable of discriminating the $\mathrm{C}$ to $\mathrm{T}$ transition, we introduced a recognition site in the wild-type allele for the restriction enzyme Bsp1286 I by altering one nucleotide ( $\mathrm{C}$ to $\mathrm{G}$ ) close to the $3^{\prime}$-end of the forward primer. DNA samples were amplified with the forward primer: $5^{\prime}$ TAG AGA AGG CTG GTC AGT GCC-3', reverse primer 5'-CTC TGG TGT GAA CAG GAG CA-3' (Bioneer). PCR was performed in a final volume of $50 \mu \mathrm{l}$, consisting of DNA (0.1 g) dNTP (0.2 mM each) (Perkin-Elmer) $\mathrm{MgCl} 2$ (2.5 mM), each primer (1.0 $\mu \mathrm{M}$ for CYP19 C1558-T), Taq polymerase (1.25 U) (Perkin-Elmer), reaction buffer, and 2\% DMSO. Amplification was performed with an initial denaturation at $9^{\circ} \mathrm{C}$ for $2 \mathrm{~min}$, followed by 30 cycles of amplification performed at $95^{\circ} \mathrm{C}$ for $30 \mathrm{~s}, 61^{\circ} \mathrm{C}$ for $30 \mathrm{~s}$, and $72^{\circ} \mathrm{C}$ for $30 \mathrm{~s}$, and a final extension at $7^{\circ} \mathrm{C}$ for $7 \mathrm{~min}$, using a GeneAmp 9600 thermal cycler (Perkin-Elmer). The PCR products were digested for $12 \mathrm{~h}$ at $37^{\circ} \mathrm{C}$ with Bsp1286 I (New England BioLabs Inc., Beverly, MA, USA), followed by size separation and the visualization of restriction fragments by electrophoresis on $2.5 \%$ agarose gels stained with ethidium bromide. Wild-type alleles with the restriction site (cleavage to $169 \mathrm{bp}+21 \mathrm{bp}$ ) were denoted $\mathrm{C}$, variant alleles (uncleaved product) without the restriction site were denoted T (190 bp).

Tetranucleotide repeat polymorphism [TTTA] $n$ genotyping

The CYP19 VNTR in intron 4 [TTTA] $n$ alleles were determined by introducing $100 \mathrm{ng}$ of genomic DNA in a PCR reaction mixture containing $10 \times$ PCR buffer, $200 \mu \mathrm{M}$ dNTPs, $2.0 \mathrm{mM} \mathrm{MgCl}_{2}$, and $0.35 \mathrm{U}$ Taq DNA polymerase (Life Technologies Ltd., Gaithersburg, Scotland, UK) to a 15- $\mu$ l total reaction volume, using $0.3 \mu \mathrm{M}$ of the following primers: forward 5'-GCA GGT ACT TAG TTA GCT AC3', reverse 5'-TTA CAG TGA GCC AAG GTC GT-3'. All PCR amplifications were carried out using a GeneAmp 9600 thermal cycler (Perkin-Elmer). The amplification parameters were as follows: $3 \mathrm{~min}$ for initial denaturation at $94^{\circ} \mathrm{C}, 30 \mathrm{~s}$ at $94^{\circ} \mathrm{C}, 35 \mathrm{~s}$ at $55^{\circ} \mathrm{C}, 7^{\circ} \mathrm{C}$ for $30 \mathrm{~s}$ - these steps were repeated for 30 cycles-final extension step at $72^{\circ} \mathrm{C}$ for $10 \mathrm{~min}$. CYP19 were analyzed in $8 \%$ and $10 \%$ polyacrylamide gels (29:1 ratio of acrylamide to bisacrylamide), respectively, and were silver stained. Genotypes were identified by UV densitometry (Gel-Doc 2000 system, Bio-Rad Laboratories Inc., Hercules, CA, USA).

Statistical analysis

Among control subjects, the genotype frequencies for each CYP19 marker were examined for deviation from the Hardy-Weinberg equilibrium (HWE) using the $X^{2}$ test. The haplotype combination at CYP19 115T>C, 240A>G, and $1531 \mathrm{C}>\mathrm{T}$ in the individuals was inferred using the maximum likelihood estimation method with the Haplotype program (http://www.people.fas.harvard.edu/ junliu/ Haplo/docMain.htm) (Niu et al. 2002). The differences in the distribution of the genotypes, haplotypes, and diplotype distributions between the groups were assessed by a Chi-square test. Logistic regression models were used to estimate odds ratios (ORs) and 95\% confidence intervals (CIs) for CYP19 genotypes and to evaluate their interaction with endometriosis. The potential confounding factors that affect endometriosis risk, such as age and body mass index (BMI), was adjusted for using logistic models in the estimation of ORs. Adjustments for these factors did not produce substantial changes in the results. We reported the results with and without adjustments for these factors. All analyses were conducted using the Statistical Package for the Social Sciences version 12.0 (SPSS Inc., Chicago, IL, USA). Pairwise linkage disequilibrium (LD) between four CYP1B1 polymorphic loci was assessed using the Haploview program (version 3.2, available at http://www.broad.mit.edu/mpg/haploview/ index.php). 


\section{Results}

We determined the frequency of the $115 \mathrm{~T}>\mathrm{C}, 240 \mathrm{~A}>\mathrm{G}$, and $1531 \mathrm{C}>\mathrm{T}$ polymorphisms of the CYP19 gene among 188 healthy control subjects in the Korean women. The distributions of the $115 \mathrm{~T}>\mathrm{C}, 240 \mathrm{~A}>\mathrm{G}$, and $1531 \mathrm{C}>\mathrm{T}$ genotypes were in Hardy-Weinberg equilibrium, and the genotype frequencies did not differ significantly between the endometriosis and control groups (Table 1). Using the homozygous wild genotype as a reference group for each polymorphism, the ORs did not differ significantly between the homozygous variant genotype and the heterozygousplus-homozygous variant genotype, even after adjusting for age and BMI (Table 2). Individual haplotypes and diplotypes of single-nucleotide polymorphisms (SNPs) were determined using the Haplotyper program. Analysis of the $115 \mathrm{~T}>\mathrm{C}, 240 \mathrm{~A}>\mathrm{G}$, and $1531 \mathrm{C}>\mathrm{T}$ SNPs revealed only six of the eight possible haplotypes. The most common haplotype and diplotype were TGT and TAC/TGT, respectively. The distribution, frequencies, and risks of the estimated haplotype combinations are listed in Table 3. The haplotype and diplotype combinations were not significantly associated with the risk of endometriosis. Significant linkage disequilibrium among the three CYP19 SNPs is evident in Table 4.

There were $8.85 \pm 2.29$ repeats $($ mean $\pm \mathrm{SD})$. The most frequent allele was [TTTA]11, followed by [TTTA]7 and [TTTA]7-3 ([TTTA]7 with an additional 3-bp deletion) in both groups. We found no significant association between the [TTTA] $n$ repeat polymorphisms and endometriosis (Table 5). Dividing the number of [TTTA] $n$ repeats into two groups (S, up to 7 repeats; $\mathrm{L}, 813$ repeats) resulted in no significant differences between the $\mathrm{S}$ and $\mathrm{L}$ groups (Table 6). Strong linkage disequilibrium was observed between the $\mathrm{T}$ genotype of $408 \mathrm{C}>\mathrm{T}$ and [TTTA] $n$ with $n=813$ (correlation coefficient of $0.621, p<0.0001$ ) (Table 7).

\section{Discussion}

Estrogen is a sex steroid that significantly affects the development of endometriosis, and, hence, genes controling the synthesis of estrogen, such as CYP19, are strong candidates for disorders associated with estrogen exposure, including endometriosis. CYP19 polymorphisms can potentially change gene expression and, thereby, affect sex-steroid action. In the present study, which is the first to investigate the association of CYP19 $115 \mathrm{~T}>\mathrm{C}, 240 \mathrm{~A}>\mathrm{G}$, and $1531 \mathrm{C}>\mathrm{T}$ polymorphisms with endometriosis, we identified $115 \mathrm{~T}>\mathrm{C}, 240 \mathrm{~A}>\mathrm{G}$, and $1531 \mathrm{C}>\mathrm{T}$ polymorphisms and [TTTA] $n$ tetranucleotide repeat polymorphisms in the CYP19 gene, and found that none of these polymorphisms or their haplotypes were significantly associated with the risk of endometriosis.

A case-control study found that the CYP19 115T $>$ C (Trp39Arg) polymorphism is significantly associated with breast cancer risk, in that this risk is significantly lower in carriers of the variant Arg (C) allele than in noncarriers in premenopausal Japanese women (Miyoshi et al. 2000; Hirose et al. 2004). Functional genomic studies performed with the Trp39Arg variant and the double variant Arg39Cys264 revealed a slight decrease in both the activity and quantity of allozyme protein for the Arg (C) allele, whereas double variant Arg39Cys264 allozymes showed significant decreases in the activity and levels of immunoreactive protein when compared with the wild-type enzyme (Ma et al. 2005). The presence of Trp39Arg in a Japanese population resulted in a less active aromatase protein (Miyoshi et al. 2000; Nativelle-Serpentini et al. 2002). In our study, the $\mathrm{C}$ genotype of the $115 \mathrm{~T}>\mathrm{C}$ polymorphism tended to decrease the risk of endometriosis, but this did not reach statistical significance. Because the allele frequency of the $\mathrm{C}$ variant of the $115 \mathrm{~T}>\mathrm{C}$ polymorphism is only $4.5 \%$ (17 cases) in Koreans, we cannot compare the

Table 1 The distribution of each of the 115T>C, 240A $>$ G, and 1531C $>$ T CYP19 genotypes

\begin{tabular}{|c|c|c|c|c|c|c|c|c|}
\hline & \multirow[t]{2}{*}{ Genotype } & \multicolumn{2}{|l|}{ Number (\%) } & \multirow[t]{2}{*}{$p$ value } & \multirow[t]{2}{*}{ Allele } & \multicolumn{2}{|l|}{ Number $(\%)$} & \multirow[t]{2}{*}{$p$ value } \\
\hline & & Control & Endometriosis & & & Control & Endometriosis & \\
\hline \multirow[t]{3}{*}{$115 \mathrm{~T}>\mathrm{C}$} & $\mathrm{TT}$ & $172(91.5 \%)$ & $213(95.5 \%)$ & \multirow[t]{3}{*}{0.07} & $\mathrm{~T}$ allele & $359(95.5 \%)$ & $436(97.8 \%)$ & \multirow[t]{3}{*}{0.07} \\
\hline & $\mathrm{TC}$ & $15(8.0 \%)$ & $10(4.5 \%)$ & & \multirow[t]{2}{*}{$\mathrm{C}$ allele } & \multirow[t]{2}{*}{$17(4.5 \%)$} & \multirow[t]{2}{*}{$10(2.2 \%)$} & \\
\hline & $\mathrm{CC}$ & $1(0.5 \%)$ & $0(0 \%)$ & & & & & \\
\hline \multirow[t]{3}{*}{$240 \mathrm{~A}>\mathrm{G}$} & AA & $54(28.7 \%)$ & $61(27.4 \%)$ & \multirow[t]{3}{*}{0.66} & A allele & $203(54.0 \%)$ & $234(52.5 \%)$ & \multirow[t]{3}{*}{0.67} \\
\hline & AG & $95(50.5 \%)$ & $112(50.2 \%)$ & & \multirow[t]{2}{*}{$\mathrm{G}$ allele } & \multirow[t]{2}{*}{$173(46.0 \%)$} & \multirow[t]{2}{*}{$212(47.5 \%)$} & \\
\hline & GG & $39(20.7 \%)$ & $50(22.4 \%)$ & & & & & \\
\hline \multirow[t]{3}{*}{$1531 \mathrm{C}>\mathrm{T}$} & $\mathrm{CC}$ & $37(19.7 \%)$ & $43(19.3 \%)$ & \multirow[t]{3}{*}{0.99} & $\mathrm{C}$ allele & $166(44.1 \%)$ & $197(44.2 \%)$ & \multirow[t]{3}{*}{0.99} \\
\hline & $\mathrm{CT}$ & $92(48.9 \%)$ & $111(49.8 \%)$ & & \multirow[t]{2}{*}{$\mathrm{T}$ allele } & \multirow[t]{2}{*}{$210(55.9 \%)$} & \multirow[t]{2}{*}{$249(55.8 \%)$} & \\
\hline & TT & $59(31.4 \%)$ & $69(30.9 \%)$ & & & & & \\
\hline
\end{tabular}




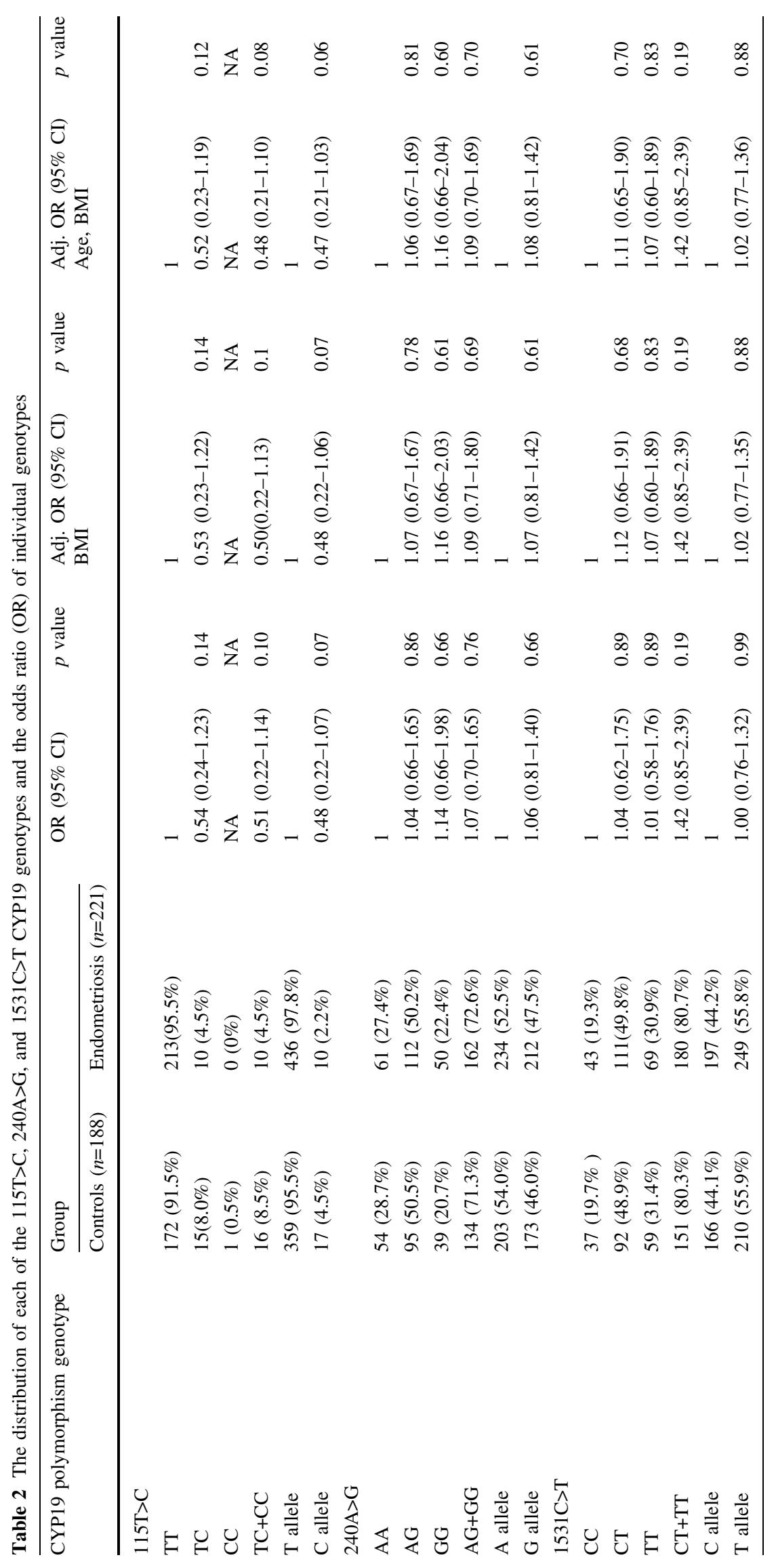


Table 3 Frequencies of diplotypes and the risk of endometriosis (115T>C, 240A >G, and 1531C>T CYP19 genotypes)

\begin{tabular}{|c|c|c|c|c|c|c|c|}
\hline \multirow{2}{*}{$\begin{array}{l}\text { Diplotype } \\
115 \mathrm{~T}>\mathrm{C}, 240 \mathrm{~A}>\mathrm{G}, 1531 \mathrm{C}>\mathrm{T}\end{array}$} & \multicolumn{3}{|l|}{ Number (\%) } & \multirow[t]{2}{*}{ OR $(95 \% \mathrm{CI})$} & \multirow[t]{2}{*}{$p$ value } & \multirow{2}{*}{$\begin{array}{l}\text { Adj. OR }(95 \% \mathrm{CI}) \\
\text { Age, BMI }\end{array}$} & \multirow[t]{2}{*}{$\overline{p \text { value }}$} \\
\hline & Total & Control & Endometriosis & & & & \\
\hline TAC/TAC & $59(14.6 \%)$ & $21(11.2 \%)$ & $38(17.5 \%)$ & 1 & & & \\
\hline TAC/TAT & $33(8.1 \%)$ & $16(8.5 \%)$ & $17(7.8 \%)$ & $0.59(0.25-1.40)$ & 0.23 & $0.56(0.23-1.34)$ & 0.19 \\
\hline TAC/TGC & $5(1.2 \%)$ & $3(1.6 \%)$ & $2(0.9 \%)$ & $0.37(0.06-2.38)$ & 0.29 & $0.36(0.05-2.34)$ & 0.28 \\
\hline TAC/TGT & $154(38.0 \%)$ & $74(39.4 \%)$ & $80(36.9 \%)$ & $0.60(0.32-1.11)$ & 0.10 & $0.62(0.33-1.16)$ & 0.14 \\
\hline TAC/CGT & $13(3.2 \%)$ & $10(5.3 \%)$ & $3(1.4 \%)$ & $0.17(0.04-0.67)$ & 0.01 & $0.18(0.04-0.73)$ & 0.02 \\
\hline TAT/TAT & $8(2.0 \%)$ & $6(3.2 \%)$ & $2(0.9 \%)$ & $0.18(0.03-0.99)$ & 0.05 & $0.19(0.04-1.05)$ & 0.06 \\
\hline TAT/TGT & $38(9.4 \%)$ & $17(9.0 \%)$ & $21(9.7 \%)$ & $0.68(0.30-1.57)$ & 0.37 & $0.74(0.32-1.70)$ & 0.47 \\
\hline TGC/TGT & $7(1.7 \%)$ & $2(1.1 \%)$ & $5(2.3 \%)$ & $1.38(0.25-7.75)$ & 0.71 & $1.61(0.28-9.21)$ & 0.59 \\
\hline TGT/TGT & $80(19.8 \%)$ & $34(18.1 \%)$ & $46(21.2 \%)$ & $0.76(0.37-1.45)$ & 0.41 & $0.80(0.40-1.62)$ & 0.54 \\
\hline TGT/CGT & $8(2.0 \%)$ & $5(2.7 \%)$ & $3(1.4 \%)$ & $0.33(0.07-1.53)$ & 0.16 & $0.20(0.04-1.16)$ & 0.07 \\
\hline Total & $405(100 \%)$ & 188 & 217 & & & & \\
\hline Haplotype & Number $(\%)$ & & & OR $(95 \% \mathrm{CI})$ & $p$ value & Adj. OR (95\% CI) & $p$ value \\
\hline $115 \mathrm{~T}>\mathrm{C}, 240 \mathrm{~A}>\mathrm{G}, 1531 \mathrm{C}>\mathrm{T}$ & Total & Control & Endometriosis & & & & \\
\hline TAC & $323(39.3 \%)$ & $145(38.6 \%)$ & $178(39.9 \%)$ & 1 & - & - & - \\
\hline TAT & $89(10.8 \%)$ & $45(12.0 \%)$ & $44(9.9 \%)$ & $0.80(0.50-1.27)$ & 0.34 & $0.80(0.50-1.28)$ & 0.80 \\
\hline TGC & $15(1.8 \%)$ & $5(1.3 \%)$ & $10(2.2 \%)$ & $1.63(0.55-4.87)$ & 0.38 & $1.67(0.55-5.04)$ & 1.67 \\
\hline TGT & $368(44.8 \%)$ & $166(44.1 \%)$ & $202(45.3 \%)$ & $0.99(0.73-1.34)$ & 0.95 & $1.03(0.76-1.39)$ & 1.03 \\
\hline $\mathrm{CAC}$ & $25(3.0 \%)$ & $15(4.0 \%)$ & $10(2.2 \%)$ & $0.54(0.24-1.25)$ & 0.15 & $0.48(0.20-1.14)$ & 0.48 \\
\hline CGT & $2(0.2 \%)$ & $0(0 \%)$ & $2(0 \%)$ & NA & NA & NA & NA \\
\hline Total & $822(100 \%)$ & $376(100 \%)$ & $10(0.2)$ & - & - & - & - \\
\hline
\end{tabular}

Table 4 Linkage disequilibrium (LD) between CYP19 polymorphisms in the Korean populations for the $115 \mathrm{~T}>\mathrm{C}, 240 \mathrm{~A}>\mathrm{G}$, and $1531 \mathrm{C}>\mathrm{T}$ genotypes

\begin{tabular}{lrll}
\hline CYP19 & LOD & D'(D' confidence bounds) & $r^{2}$ \\
\hline $115 \mathrm{~T}>\mathrm{C}-240 \mathrm{~A}>\mathrm{G}$ & 2.97 & $0.87(0.47-0.97)$ & 0.02 \\
$115 \mathrm{~T}>\mathrm{C}-1531 \mathrm{C}>\mathrm{T}$ & 4.02 & $0.82(0.51-0.94)$ & 0.03 \\
$240 \mathrm{~A}>\mathrm{G}-1531 \mathrm{C}>\mathrm{T}$ & 73.76 & $0.90(0.85-0.94)$ & 0.57 \\
\hline
\end{tabular}

effect of this allele with the results from studies performed on other ethnic groups.

In our study, a synonymous polymorphism 240A $>\mathrm{G}$ (codon 80) in exon 3 (A genotype carrier) did not affect the risk of endometriosis development. The $240 \mathrm{~A}>\mathrm{G}$ polymorphism was associated with breast cancer in postmenopausal Caucasian women, and the serum estradiol concentrations were higher in women with the AA genotype than in those with the GG genotype. All of our subjects were premenopausal, whereas the other breast cancer and hormone studies involved postmenopausal women, and, hence, the differing results might be due to the circumstances and role of the CYP19 enzyme in estrogen metabolism differing with the menopausal status.
For the CYP19 1531C>T transition in the $3^{\prime}$ untranslated region of exon 10, women with the $\mathrm{T}$ allele had significantly lower levels of testosterone, androstenedione, DHEA, and DHEAS. A significantly greater estrone:androstenedione ratio supports the hypothesis that the $\mathrm{T}$ allele elevates aromatase activity (Haiman et al. 2002). The variant $\mathrm{T}$ allele was previously suggested to be associated with a high estrogen profile because it was correlated with tumor aromatase mRNA levels. The variant $\mathrm{T}$ allele is associated with alternative promoter use (Somner et al. 2004), and Kristensen et al. (2000) found that it was more frequent in breast cancer cases than in their controls. Other studies have found no association between the $1531 \mathrm{C}>\mathrm{T}$ polymorphism and breast cancer risk, and the present study found that the CYP19 1531C $>$ T polymorphism is not associated with the risk of endometriosis. Our results are consistent with the recent study by Travis et al. (2004) suggesting the absence of an association between the CYP19 1531C>T polymorphism and plasma estradiol concentrations in postmenopausal women.

We found a tetranucleotide tandem repeat polymorphism that varies from 7 to 13 repeats in intron 4, and with an additional 3-bp deletion, although no data exist on the functionality of either the tetranucleotide repeat or the 
Table 5 CYP19 intron 4 [TTTA] $n$ repeat allele frequencies in endometriosis and controls

\begin{tabular}{lllll}
\hline CYP19 & Group & OR (95\% CI) & $p$ value \\
\cline { 2 - 4 } Repeat number & Control alleles $(n=376)$ & Endometriosis alleles $(n=448)$ & & \\
\hline [TTTA]7-TCT & $81(21.5 \%)$ & $97(21.7 \%)$ & 1 & \\
[TTTA]7+TCT & $116(30.9 \%)$ & $129(28.8 \%)$ & $0.93(0.63-1.37)$ & 0.71 \\
[TTTA]11 & $134(35.6 \%)$ & $159(35.5 \%)$ & $1.95(0.49-7.78)$ & 0.35 \\
[TTTA]12 & $38(10.1 \%)$ & $54(12.1 \%)$ & $1.19(0.71-1.97)$ & 0.51 \\
Others & $7(1.95 \%)$ & $9(2.0 \%)$ & $1.070(0.37-3.01)$ & 0.78 \\
\hline
\end{tabular}

Table 6 The distribution of the CYP19 intron 4 [TTTA] $n$ repeat allele frequencies and ORs of the individual genotypes. The OR of the SS genotype was considered as the reference

\begin{tabular}{|c|c|c|c|c|c|c|}
\hline \multirow[t]{2}{*}{ CYP19 repeat } & \multicolumn{2}{|l|}{ Group } & \multirow[t]{2}{*}{ OR $(95 \% \mathrm{CI})$} & \multirow[t]{2}{*}{$p$ value } & \multirow[t]{2}{*}{$\mathrm{OR}^{\mathrm{Adj}}(95 \% \mathrm{CI})$} & \multirow[t]{2}{*}{$P^{\text {Adj }}$ value } \\
\hline & Controls $(n=188)$ & Endometriosis $(n=224)$ & & & & \\
\hline SS & $50(26.6 \%)$ & $55(24.6 \%)$ & 1 & & & \\
\hline SL & $97(51.6 \%)$ & $116(51.8 \%)$ & $1.09(0.68-1.74)$ & 0.73 & $1.10(0.68-1.77)$ & 0.70 \\
\hline LL & $41(21.8 \%)$ & $53(23.7 \%)$ & $1.18(0.67-2.06)$ & 0.57 & $1.21(0.69-2.14)$ & 0.50 \\
\hline $\mathrm{SS}+\mathrm{SL}$ & $147(78.2 \%)$ & $171(76.3 \%)$ & 1 & 1 & 1 & 1 \\
\hline LL & $41(21.8 \%)$ & $53(23.7 \%)$ & $1.11(0.70-1.77)$ & 0.66 & $1.14(0.71-1.82)$ & 0.56 \\
\hline
\end{tabular}

Table 7 Association between two polymorphisms in the CYP19 gene tetranucleotide repeat in intron 4 and CYP19 1531C>T

\begin{tabular}{lrrr}
\hline CYP19 repeat number & \multicolumn{4}{c}{ CYP19 } & $408 \mathrm{C}>\mathrm{T}$ & \\
\cline { 2 - 4 } & CC & CT & TT \\
\hline SS & 60 & 36 & 9 \\
SL & 14 & 158 & 41 \\
LL & 6 & 10 & 78 \\
\hline
\end{tabular}

deletion polymorphisms. The different genetic variants may lead to alternate splicing patterns and mRNA transcripts, which could, ultimately, modify the activity of the resulting protein. On the other hand, the intratumoral aromatase activity tended to be higher in carriers of the longest CYP19 alleles than in carriers of all other CYP19 allele variants. The [TTTA]10 allele was found to be associated with endometriosis (Arvanitis et al. 2003), and several studies have failed to show associations between [TTTA] $n$ repeat polymorphisms (including the 3-bp I/D polymorphism) and the risks of breast cancer and endometriosis (Probst-Hensch et al. 1999; Healey et al. 2000). A Japanese study found no significant association between [TTTA] $n$ repeat polymorphisms and endometriosis, but patients carrying the $\mathrm{D} / \mathrm{D}$ genotype were more frequent in the endometriosis group than in their control group (Kado et al. 2002), especially in subgroups with a chocolate cyst. The present study found that advanced-stage endometriosis was not associated with [TTTA] $n$ repeat polymorphisms (including the 3-bp I/D polymorphism), despite the severity of endometriosis in our patients being similar to that in the Japanese study. Differences in the distributions of tetranucleotide repeats or deletion polymorphisms might be responsible for different results in association studies.

In present study, the CYP19 [TTTA] $n$ polymorphisms were in linkage disequilibrium with the $1531 \mathrm{C}>\mathrm{T}$ polymorphism (correlation coefficient of $0.621, p<0.0001$ ), and the number of repeats was highest in women with the TT genotype (11 repeats), which is consistent with a Danish study (Tofteng et al. 2004).

Our finding of the absence of an association between CYP19 polymorphisms and the risk of endometriosis is consistent with a Japanese study finding no association between the Arg264Cys polymorphism and endometriosis (Tsuchiya et al. 2005). The CYP19 gene appears to have a limited number of common haplotypes and many very rare haplotypes. The haplotype associated with the risk of endometrial cancer in postmenopausal women is also significantly associated with the ratios of estrone to androstenedione and estradiol to testosterone, which are products and substrates of the enzyme aromatase that are encoded by CYP19 (Paynter et al. 2005). However, in our study, we found no association between haplotype and the risk of endometriosis, which might be due to the different menstrual status of our subjects.

The strengths of this study include the relatively large number of endometriosis cases and the use of Korean female subjects, who are considered to be genetically homogenous. 
In conclusion, endometriosis does not appear to be associated with CYP19 polymorphisms, and, hence, the genotypes and haplotype frequencies of these polymorphisms are probably not useful markers for predicting susceptibility to endometriosis.

Acknowledgment This work was supported by a Korea Research Foundation Grant (KRF-2004-041-E00192).

\section{References}

American Fertility Society (1985) Revised American Fertility Society classification of endometriosis: 1985. Fertil Steril 43:351-352

Arvanitis DA, Koumantakis GE, Goumenou AG, Matalliotakis IM, Koumantakis EE, Spandidos DA (2003) CYP1A1, CYP19, and GSTM1 polymorphisms increase the risk of endometriosis. Fertil Steril 79:702-709

Baranova H, Bothorishvilli R, Canis M, Albuisson E, Perriot S, Glowaczower E, Bruhat MA, Baranov V, Malet P (1997) Glutathione S-transferase M1 gene polymorphism and susceptibility to endometriosis in a French population. Mol Hum Reprod 3:775-780

Bergqvist A, Fernö M (1993) Oestrogen and progesterone receptors in endometriotic tissue and endometrium: comparison of different cycle phases and ages. Hum Reprod 8:2211-2217

Bulun SE, Fang Z, Imir G, Gurates B, Tamura M, Yilmaz B, Langoi D, Amin S, Yang S, Deb S (2004) Aromatase and endometriosis. Semin Reprod Med 22:45-50

Bulun SE, Imir G, Utsunomiya H, Thung S, Gurates B, Tamura M, Lin $\mathrm{Z}$ (2005) Aromatase in endometriosis and uterine leiomyomata. J Steroid Biochem Mol Biol 95:57-62

Chang CC, Hsieh YY, Tsai FJ, Tsai CH, Tsai HD, Lin CC (2002) The proline form of p53 codon 72 polymorphism is associated with endometriosis. Fertil Steril 77:43-45

Cramer DW, Hornstein MD, Ng WG, Barbieri RL (1996) Endometriosis associated with the N314D mutation of galactose-1phosphate uridyl transferase (GALT). Mol Hum Reprod 2:149152

Georgiou I, Syrrou M, Bouba I, Dalkalitsis N, Paschopoulos M, Navrozoglou I, Lolis D (1999) Association of estrogen receptor gene polymorphisms with endometriosis. Fertil Steril 72:164 166

Haiman CA, Hankinson SE, Spiegelman D, Brown M, Hunter DJ (2002) No association between a single nucleotide polymorphism in CYP19 and breast cancer risk. Cancer Epidemiol Biomarkers Prev 11:215-216

Healey CS, Dunning AM, Durocher F, Teare D, Pharoah PD, Luben RN, Easton DF, Ponder BA (2000) Polymorphisms in the human aromatase cytochrome P450 gene (CYP19) and breast cancer risk. Carcinogenesis 21:189-193

Hirose K, Matsuo K, Toyama T, Iwata H, Hamajima N, Tajima K (2004) The CYP19 gene codon 39 Trp/Arg polymorphism increases breast cancer risk in subsets of premenopausal Japanese. Cancer Epidemiol Biomarkers Prev 13:1407-1411

Hur SE, Lee JY, Moon H-S, Chung HW (2005) Polymorphisms of the genes encoding the GSTM1, GSTT1 and GSTP1 in Korean women: no association with endometriosis. Mol Hum Reprod 11:15-19

Kado N, Kitawaki J, Obayashi H, Ishihara H, Koshiba H, Kusuki I, Tsukamoto K, Hasegawa G, Nakamura N, Yoshikawa T, Honjo $\mathrm{H}$ (2002) Association of the CYP17 gene and CYP19 gene polymorphisms with risk of endometriosis in Japanese women. Hum Reprod 17:897-902
Kennedy SH (1997) Is there a genetic basis to endometriosis? Semin Reprod Endocrinol 5:309-318

Kitawaki J, Noguchi T, Amatsu T, Maeda K, Tsukamoto K, Yamamoto T, Fushiki S, Osawa Y, Honjo H (1997) Expression of aromatase cytochrome $\mathrm{P} 450$ protein and messenger ribonucleic acid in human endometriotic and adenomyotic tissues but not in normal endometrium. Biol Reprod 57:514-519

Kitawaki J, Kusuki I, Koshiba H, Tsukamoto K, Fushiki S, Honjo H (1999) Detection of aromatase cytochrome P-450 in endometrial biopsy specimens as a diagnostic test for endometriosis. Fertil Steril 72:1100-1106

Kitawaki J, Obayashi H, Ishihara H, Koshiba H, Kusuki I, Kado N, Tsukamoto K, Hasegawa G, Nakamura N, Honjo H (2001) Oestrogen receptor-alpha gene polymorphism is associated with endometriosis, adenomyosis and leiomyomata. Hum Reprod $16: 51-55$

Kristensen VN, Harada N, Yoshimura N, Haraldsen E, Lonning PE, Erikstein B, Kåresen R, Kristensen T, Borresen-Dale AL (2000) Genetic variants of CYP19 (aromatase) and breast cancer risk. Oncogene 19:1329-1333

Lee KM, Abel J, Ko Y, Harth V, Park WY, Seo JS, Yoo KY, Choi JY, Shin A, Ahn SH, Noh DY, Hirvonen A, Kang D (2003) Genetic polymorphisms of cytochrome P450 19 and 1B1, alcohol use, and breast cancer risk in Korean women. Br J Cancer 88:675678

Lessey BA, Metzger DA, Haney AF, McCarty KS Jr (1989) Immunohistochemical analysis of estrogen and progesterone receptors in endometriosis: comparison with normal endometrium during the menstrual cycle and the effect of medical therapy. Fertil Steril 51:409-415

Ma CX, Adjei AA, Salavaggione OE, Coronel J, Pelleymounter L, Wang L, Eckloff BW, Schaid D, Wieben ED, Adjei AA, Weinshilboum RM (2005) Human aromatase: gene resequencing and functional genomics. Cancer Res 65:11071-11082

Miyoshi Y, Iwao K, Ikeda N, Egawa C, Noguchi S (2000) Breast cancer risk associated with polymorphism in CYP19 in Japanese women. Int J Cancer 89:325-328

Nativelle-Serpentini C, Lambard S, Séralini GE, Sourdaine P (2002) Aromatase and breast cancer: W39R, an inactive protein. Eur J Endocrinol 146:583-589

Niu T, Qin ZS, Xu X, Liu JS (2002) Bayesian haplotype inference for multiple linked single-nucleotide polymorphism. Am J Hum Genet 70:157-169

Paynter RA, Hankinson SE, Colditz GA, Kraft P, Hunter DJ, De Vivo I (2005) CYP19 (aromatase) haplotypes and endometrial cancer risk. Int J Cancer 116:267-274

Prentice A, Randall BJ, Weddell A, McGill A, Henry L, Horne CHW, Thomas EJ (1992) Ovarian steroid receptor expression in endometriosis and in two potential parent epithelia: endometrium and peritoneal mesothelium. Hum Reprod 7:1318-1325

Probst-Hensch NM, Ingles SA, Diep AT, Haile RW, Stanczyk FZ, Kolonel LN, Henderson BE (1999) Aromatase and breast cancer susceptibility. Endocr Relat Cancer 6:165-173

Siegelmann-Danieli N, Buetow KH (1999) Constitutional genetic variation at the human aromatase gene (CYP19) and breast cancer risk. Br J Cancer 79:456-463

Somner J, McLellan S, Cheung J, Mak YT, Frost ML, Knapp KM, Wierzbicki AS, Wheeler M, Fogelman I, Ralston SH, Hampson GN (2004) Polymorphisms in the P450 c17 (17-hydroxylase/17,20-Lyase) and P450 c19 (aromatase) genes: association with serum sex steroid concentrations and bone mineral density in postmenopausal women. J Clin Endocrinol Metab 89:344-351

Sourdaine P, Parker MG, Telford J, Miller WR (1994) Analysis of the aromatase cytochrome $\mathrm{P} 450$ gene in human breast cancers. J Mol Endocrinol 13:331-337 
Toda K, Terashima M, Kawamoto T, Sumimoto H, Yokoyama Y, Kuribayashi I, Mitsuuchi Y, Maeda T, Yamamoto Y, Sagara Y (1990) Structural and functional characterization of human aromatase P-450 gene. Eur J Biochem 193:559-565

Tofteng CL, Kindmark A, Brändstrom H, Abrahamsen B, Petersen S, Stiger F, Stilgren LS, Jensen JEB, Vestergaard P, Langdahl BL, Mosekilde L (2004) Polymorphisms in the CYP19 and AR genes-relation to bone mass and longitudinal bone changes in postmenopausal women with or without hormone replacement therapy: the Danish Osteoporosis Prevention Study. Calcif Tissue Int 74:25-34

Travis RC, Churchman M, Edwards SA, Smith G, Verkasalo PK, Wolf CR, Wolf H, Key TJ (2004) No association of polymorphisms in CYP17, CYP19, and HSD17-B1 with plasma estradiol concentrations in 1,090 British women. Cancer Epidemiol Biomarkers Prev 13:2282-2284
Tsuchiya M, Nakao H, Katoh T, Sasaki H, Hiroshima M, Tanaka T, Matsunaga T, Hanaoka T, Tsugane S, Ikenoue T (2005) Association between endometriosis and genetic polymorphisms of the estradiol-synthesizing enzyme genes HSD17B1 and CYP19. Human Reprod 20:974-978

Watanabe T, Imoto I, Kosugi Y, Fukuda Y, Mimura J, Fujii Y, Isaka K, Takayama M, Sato A, Inazawa J (2001) Human arylhydrocarbon receptor repressor (AHRR) gene: genomic structure and analysis of polymorphism in endometriosis. J Hum Genet 46:342-346

Wieser F, Schneeberger C, Tong D, Tempfer C, Huber JC, Wenzl R (2002) PROGINS receptor gene polymorphism is associated with endometriosis. Fertil Steril 77:309-312 